\title{
Energy and Environmental Issues in Manufacturing Industries
}

\author{
Xingbo Liu
}

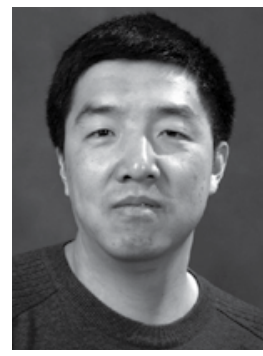

In the TMS community, more and more attention has been paid to improving energy efficiency and reducing greenhouse gas (GHG) emissions in both manufacturing and daily life, but no specific committee has addressed these issues. Not anymore. During the TMS 2008 Annual Meeting in New Orleans, the Energy Committee was formed as an interdisciplinary committee of both the TMS Extraction \& Processing and Light Metals divisions. The mission of the committee is to promote sustainable production and manufacturing of minerals, metals, and materials by fostering technical solutions to increase process efficiency, decrease energy consumption, minimize process emissions, and apply alternate sources of energy in material production processes.

As noted by the committee chair, Neale R. Neelameggham, in the future the Energy Committee plans to provide key programming in the following areas: metallurgical/chemical reduction of feedstock; process materials and effluents; technologies to improve the energy efficiency of industrial and manufacturing processes related to minerals, metals, and materials; alternative energy sources for conventional material production processes; and co-generation technologies, including capture and re-use of process emissions and gases as well as energy component recycling technologies and technologies to minimize thermal emissions.

This issue of JOM includes four papers focusing on the areas of interest for the Energy Committee. A well-managed energy program can be a successful method to reduce energy consumption and energy cost in a manufacturing environment. There are many aspects to such a program, with the most frequently considered aspect, the modification of equipment, probably not the most important.

"A New Integrated Lean Manufacturing Model for Magnesium Products" by F. D'Errico et al. presents the life cycle assessment, including an analysis of minerals, energy resource processing, manufacturing steps, logistics, re-use, and recycling routes on the magnesium alloy products that are manufactured by the semisolid injection molding (SSIM) process. The results show that SSIM realizes energy savings due to its lowest specific energy per kilogram of shaped metal material. It is possible to substitute $154 \mathrm{~kg}$ of magnesium on vehicles that can lead to a decrease in GHG emissions of about $17 \%$, without considering further weight savings induced by downsizing the other not-substitutable steel or aluminum parts.

"Elements of an Energy Management Program" by Ray D. Peterson and Cynthia K. Belt describes the key elements of energy management in the aluminum metals industry. Process identification, data collection, data analysis, project selection, implementation, and communications are reviewed.

Neale R. Neelameggham discusses an interesting and important issue-the role of metal ions in photosynthesis and biomass formation, in his paper titled "Soda-Fuel Metallurgy: Metal Ions for Carbon-Neutral $\mathrm{CO}_{2}$ and $\mathrm{H}_{2} \mathrm{O}$ Reduction ()." His analyses show that it is possible to design an industrial process mimicking biomass production making it carbon neutral at the energy use sources. To do that, we should develop electrolytic cells with special membranes, which would allow inhalation of carbon dioxide into the electrolytic zone while exhaling oxygen. Balanced mixtures of the metal cations in such electrolysis can also supply the simultaneous conversion of atmospheric nitrogen into amino compounds or ammonium ions which will improve solubility of $\mathrm{CO}_{2}$ and the assimilation and conversion of $\mathrm{CO}_{2}$ into fuels.

Sergey Shabala summarizes basic requirements and major functions for each of the metal ions as nutrients in plant photosynthesis, both at the whole-plant and molecular level in "Metal Cations in $\mathrm{CO}_{2}$ Assimilation and Conversion by Plants." He also presents how these requirements may be affected by global climate trends and the prospects of creating artificial photosynthetic "bioreactors" for efficient energy conversion and $\mathrm{CO}_{2}$ assimilation. The author concludes that artificial photosynthesis offers a viable economic strategy for moving toward the use of renewable energy resources.

At the TMS 2009 Annual Meeting, two symposia were organized by the Energy Committee: $\mathrm{CO}_{2}$ Reduction Metallurgy 2009, organized by Neelameggham, Ramana Reddy, Jiann-Yang Hwang, and Jean-Pierre Birat; and Energy Conservation in Metals Extraction and Materials Processing II, organized by Edgar Vidal, Cynthia Belt, Marie Kistler, Mark Cooksey, and Rob Hardin. At TMS 2010, these two will continue, and we plan to organize at least two more symposia that focus on energy and environmental issues.

Xingbo Liu is an assistant professor in the Mechanical \& Aerospace Engineering Department at West Virginia University and is the JOM advisor from the Energy Committee of the TMS Extraction \& Processing Division and Light Metals Division. He can be reached at xingbo.liu@mail.wvu.edu. 